\title{
Changes in weed infestation of spring barley depending on variable pluvio-thermal conditions
}

\author{
Roman Krawczyk, Roman Kierzek*, Kazimierz Adamczewski \\ Department of Weed Science and Plant Protection Techniques, Plant Protection Institute - National Research Institute, Władysława Węgorka 20, 60-318 Poznań, Poland
}

\begin{abstract}
The aim of the study was to analyze segetal weeds present in spring barley against the background of changes in pluviothermal conditions observed over the last 20 years (1993-2012) at the Field Experimental Station of the Institute of Plant Protection - National Research Institute in Winna Góra, Poland. Based on the mean value of the Sielianinov hydrothermal coefficient for the three months of spring vegetation, i.e., April, May, and June, three classes of pluvio-thermal conditions (very dry, moderately dry, humid) were distinguished. The phytosociological stability of weed species analyzed during the study period was assessed and the Shannon-Wiener index of species diversity in the communities and the Simpson dominance index were calculated for segetal weeds present in spring barley.

In the 20-year period analyzed, Chenopodium album and Viola arvensis exhibited the highest phytosociological stability and the highest abundance in the spring barley crop. Over the years analyzed, the dry spring vegetation periods were characterized by significant precipitation deficiency between late April and mid-June. In the years with favorable meteorological conditions, the weed species diversity measured by the Shannon-Wiener diversity index was higher than in the years with precipitation deficiency. In the very dry years, the species dominance index in the spring vegetation period was higher than in the wet years. The yield loss caused by weed infestation in the very dry years was higher by $6 \%$ as compared to moderately dry and wet years.
\end{abstract}

Keywords: weeds; phytosociological stability; spring barley; pluvio-thermal conditions; 20-year period

\section{Introduction}

The area of spring barley cultivation in Poland is more than 900 thousand ha, which accounts for over $14 \%$ of the cereal structure [1]. Thus, this species covers the greatest area of all spring cereals grown. Early-sown spring barley is highly tolerant to adverse weather conditions, in particular to precipitation deficiency [2]. Yields and growth of this crop plant are markedly influenced by the abundance and species composition of weeds [3]. Approximately 200 among the hundreds of weed species may infest agricultural crops [4]. In the sixties of the last century, the basic agricultural crops were infested by an average of 40 weed species, whereas a phenomenon of a widespread increase in field infestation rates was observed worldwide in the eighties. Currently, spring cereals, including barley, are infested by a few to several dozen species, whose number seldom exceeds 20 [5]. Changes in the quantities and species composition in segetal flora caused by production globalization processes,

\footnotetext{
* Corresponding author. Email: r.kierzek@vp.pl
}

Handling Editor: Elżbieta Weryszko-Chmielewska a reduction in crop rotation and agronomic treatments as well as application of mineral fertilizers and weed control agents lead to the dominance of one or a few weed species [6-14]. Herbicides do not impoverish the agrophytocoenosis, as they limit the abundance rather than the diversity of weeds $[15,16]$. As reported by Sienkiewicz [17], besides anthropopressure, climate changes contribute to the disappearance of weed species and reduced weed species diversity. Meteorological conditions have an impact on the efficacy of herbicide treatments $[18,19]$. The rate of weed infestation is influenced by soil moisture [20-23]. The climate in Poland is characterized by high variability of the individual climate elements, including air temperature and precipitation [24,25]. In several-year investigations, it is difficult to identify trends in changes in the biodiversity of segetal flora due to the complexity of the multiple factors affecting the process [26]. However, the determination of the tendencies of weed changes occurring in agrocenoses is possible in multi-year research.

The aim of the study was to analyze segetal weeds present in spring barley against the background of agronomic management and changes in pluvio-thermal conditions observed over the last 20 years (1993-2012). 


\section{Material and methods}

Data concerning weed infestation were obtained from field experiments conducted over the period 1993-2012 at the Field Experimental Station (FES) in Winna Góra $\left(52^{\circ} 12^{\prime} \mathrm{N} ; 17^{\circ} 27^{\prime} \mathrm{E}\right)$ managed by the Institute of Plant Protection - National Research Institute, Poland. The experiment was established on lessive soil formed of loamy sand or sandy loam assigned to quality class IIIa-IVa. The results of temperature and precipitation measurements were provided by the meteorological station located in Winna Góra FES. Assessment of pluvio-thermal conditions for the analyzed period of 1993-2012 (April, May, and June) was carried out using the Sielianinov hydrothermal coefficient: $k=(P$ $\times 10$ ) / $T$, where: $P$ - monthly precipitation sum in $\mathrm{mm}$, $T$ - monthly sum of mean air temperatures

Based on the mean value of the coefficient $k$ for the three months of spring vegetation, i.e., April, May, and June, three classes of coefficient $k$ values differing in terms of pluviothermal conditions were distinguished. These comprised the following ranges of the coefficient $k$ : $\mathrm{A}-$ dry: $k \leq 0.7$; $\mathrm{B}$ - moderately dry: $0.7<k \leq 1.3$; C - humid: $k>1.3$.

Spring barley was cultivated in the plough-based system. In the experiment, balanced mineral fertilization as well as pest and pathogen control agents were applied as a standard. Every year, two experimental treatments with an area from 400 to $1000 \mathrm{~m}^{2}$ were randomly established: 1 - without herbicide weed control; 2 - with herbicide weed control.

Each treatment comprised four $16.5 \mathrm{~m}^{2}$ experimental plots. The species composition and number of weeds in the herbicide-untreated plots were determined using the frame method. The weeds were counted in a $0.25 \mathrm{~m}^{2}$ area in four randomly chosen sites in each plot (16 replicates in each treatment) in the period from stem elongation to the heading stage of spring barley (BBCH 39/59). The plant nomenclature was adopted after Mirek et al. [27].

In terms of phytosociological stability $\left(\mathrm{S}^{*}\right)$ of the species analyzed in the study years [28], five classes were distinguished according to the Braun-Blanquet scale [29]: V - very frequent species $(80.1-100 \%$ frequency in the study years); IV - frequent species $(60.1-80 \%$ frequency in the study years); III - medium-frequent species (40.1-60\% frequency in the study years); II - infrequent species $(20.1-40 \%$ frequency in the study years); I - sporadic species (up to $20 \%$ in the study years). The Shannon-Wiener index of species diversity in the communities and the Simpson dominance index were calculated from the collected data [30,31]. The index of species dominance in the weed community were derived on the basis of the highest values calculated from the square ratio of their number to the total number of all individuals in the weed community $\left(p_{i}^{2}\right)$. The ecological indices were calculated using the following equations: Shannon-Wiener's diversity index: $H^{\prime}=-\Sigma\left(p_{i} \ln p_{i}\right)$; Simpson's dominance index: $\lambda=\Sigma p_{i}^{2}$, where: $p_{i}$ - number of individuals of the $i$-th species in the community to the total number of all individuals in the community

The values of Simpson's index of species dominance range from 0 to 1, with higher values indicating the dominance of one or several species in the community [32]. Spring barley grain was harvested using a Wintersteiger plot combine. The yield collected from the plots was converted to $14 \%$ grain moisture. The results obtained were shown in relative values as a percentage of the yield from the plot untreated with herbicides to that from the treated plot (without weeds).

Principal component analysis (PCA) was used to assess the variation of weed species composition [33]. The influence of environmental variables (pluvio-thermal conditions) on the weed community was evaluated using canonical correspondence analysis (CCA) [34]. Pearson's correlation coefficients were used to establish relationship between selected variables. The significance level was $\alpha=0.05$.

\section{Results}

In the analyzed period, 25 weed species were identified in the spring barley crop, including 23 species of the class Magnoliopsida, one species of the class Liliopsida (Echinochloa crus-galli), and one species within the class Sphenopsida (Equisetum arvense). In the analyzed period (1993-2012), the most frequent were two species, Chenopodium album (43.8 $\left.\mathrm{pcs} / \mathrm{m}^{2}\right)$ and Viola arvensis $\left(20.7 \mathrm{pcs} / \mathrm{m}^{2}\right)$, with the highest degree of phytosociological constancy (Tab. 1).

The pluvio-thermal conditions during the early growing season impacted spring barley infestation by weeds. Over the period 1993-2012, dry weather conditions prevailed in April, while extremely dry and very dry conditions were usually reported in May. In accordance with the classification of pluvio-thermal conditions adopted in the present study, the analyzed period comprised six years with a dry $(k \leq 0.7)$ spring vegetation period $(1993,1998,2000,2003$, $2008,2011)$, eight moderately dry years $(0.7<k \leq 1.3)$ in April-June (1994, 1995, 1997, 2002, 2004, 2006, 2007, 2012), and five years with a wet vegetation period (1996, 1999, 2001, $2009,2010)$. Despite the higher number of weed species in the very dry years, the species diversity measured by the Shannon-Wiener diversity index $\left(H^{\prime}\right)$ was lower than in the moderately dry and humid years (Fig. 1). The lower values calculated for the Shannon-Wiener diversity index in the dry years resulted from a smaller number of individuals within a species with the lowest degree of phytosociological constancy. Pluvio-thermal conditions affected the quantitative structure of weed species composition in spring barley. In the very dry years, the Simpson index of species dominance $(\lambda)$ was higher as compared to the moderately dry and dry vegetation periods $(0.47,0.43$ and 0.39 , respectively; Fig. 2$)$.

The dominant species Chenopodium album and Viola arvensis exhibited a significantly positive correlation to share in spring barley crop (46\%; Fig. 3). Viola arvensis was strongly associated with Myosotis arvensis, Lamium amplexicaule (both at a level of 93\%) and Geranium pusillum (62\%). Galium aparine was significantly correlated with poll (51\%) and Brassica napus volunteer (48\%). A significant correlation was found between Cirsium arvense and Polygonum aviculare (83\%) and C. arvense and Geranium pusillum (47\%). The highest positive correlation was observed between Sonchus arvensis and Equisetum arvense as well as between Lamium amplexicaule and Myosotis arvensis.

The present study demonstrates varying dynamics of weed infestation depending on the pluvio-thermal conditions 
Tab. 1 Phytosociological stability of species and the average number of weeds (plants $\mathrm{m}^{-2}$ ) noted in 1993-2012 in spring barley crops.

\begin{tabular}{|c|c|c|c|}
\hline No. & Species & $\begin{array}{l}\text { Phytosociological } \\
\text { stability }\left(S^{*}\right)\end{array}$ & $\begin{array}{l}\text { Average number of } \\
\text { weeds during the study } \\
\text { period (plants } \mathrm{m}^{-2} \text { ) }\end{array}$ \\
\hline 1 & Chenopodium album $\mathrm{L}$. & $\mathrm{V}$ & 43.8 \\
\hline 2 & Viola arvensis Murray & $\mathrm{V}$ & 20.7 \\
\hline 3 & Galium aparine $\mathrm{L}$. & III & 5.5 \\
\hline 4 & $\begin{array}{l}\text { Matricaria maritima subsp. inodora (L.) } \\
\text { Dostál }\end{array}$ & III & 5.2 \\
\hline 5 & Thlaspi arvense $\mathrm{L}$. & II & 6.0 \\
\hline 6 & Stellaria media (L.) Vill. & II & 3.9 \\
\hline 7 & Fallopia convolvulus (L.) Á. Löve & II & 3.6 \\
\hline 8 & Polygonum lapathifolium L. & II & 3.5 \\
\hline 9 & Capsella bursa-pastoris (L.) Medik. & II & 3.1 \\
\hline 10 & Anthemis arvensis $\mathrm{L}$. & I & 7.5 \\
\hline 11 & Veronica hederifolia (L.) s.s. & I & 5.5 \\
\hline 12 & Brassica napus L. subsp. napus & I & 5.3 \\
\hline 13 & Centaurea cyanus $\mathrm{L}$. & I & 5.3 \\
\hline 14 & Echinochloa crus-galli (L.) P. Beauv. & I & 4.0 \\
\hline 15 & Lamium amplexicaule $\mathrm{L}$. & I & 3.8 \\
\hline 16 & Veronica arvensis $\mathrm{L}$. & I & 3.1 \\
\hline 17 & Cirsium arvense (L.) Scop. & I & 2.9 \\
\hline 18 & Myosotis arvensis (L.) Hill & I & 2.8 \\
\hline 19 & Sonchus arvensis $\mathrm{L}$. & I & 2.3 \\
\hline 20 & Anchusa arvensis (L.) M. Bieb. & I & 2.0 \\
\hline 21 & Polygonum aviculare $\mathrm{L}$. & I & 1.5 \\
\hline 22 & Amaranthus retroflexus $\mathrm{L}$. & I & 1.4 \\
\hline 23 & Geranium pusillum Burm. f. ex L. & I & 1.4 \\
\hline 24 & Papaver rhoeas L. & I & 1.0 \\
\hline 25 & Equisetum arvense $\mathrm{L}$. & I & 0.3 \\
\hline
\end{tabular}

$S^{*}: \mathrm{V}$ - very frequent species; IV - frequent species; III - medium-frequent species; II - infrequent species; I - sporadic species.

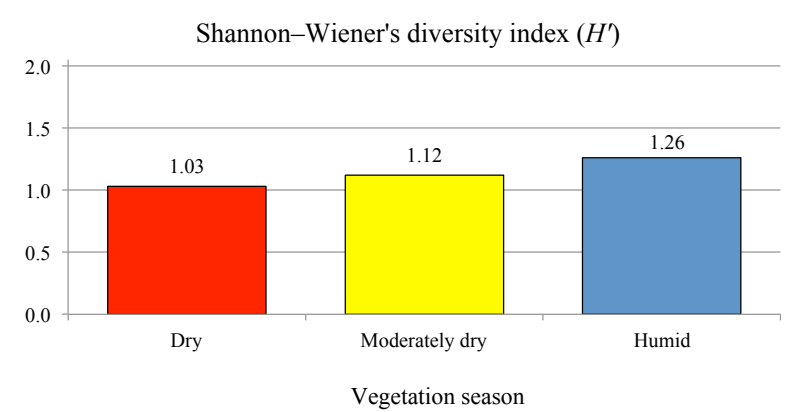

Fig. 1 The Shannon-Wiener diversity index $\left(H^{\prime}\right)$ calculated for weed species in spring barley crops depending on pluviothermal conditions (April-June) in Winna Góra (the means from 1993-2012).

prevailing during the spring vegetation period. The weather conditions had less effect on the occurrence of the following species: Chenopodium album, Viola arvensis and Galium aparine (Fig. 4). In dry conditions, the occurrence

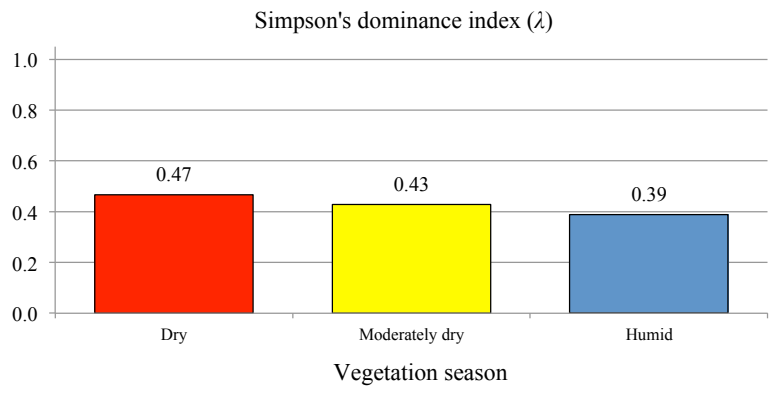

Fig. 2 Simpson's dominance index $(\lambda)$ calculated for weed species in spring barley crops depending on pluvio-thermal conditions (April-June) in Winna Góra (the means from 1993-2012).

of Equisetum arvense, Sonchus arvensis and Papaver rhoeas was noted. The occurrence of Polygonum aviculare, Cirsium arvense, Anthemis arvensis, Veronica hederifolia, and Fallopia convolvulus was more associated with humid conditions. 


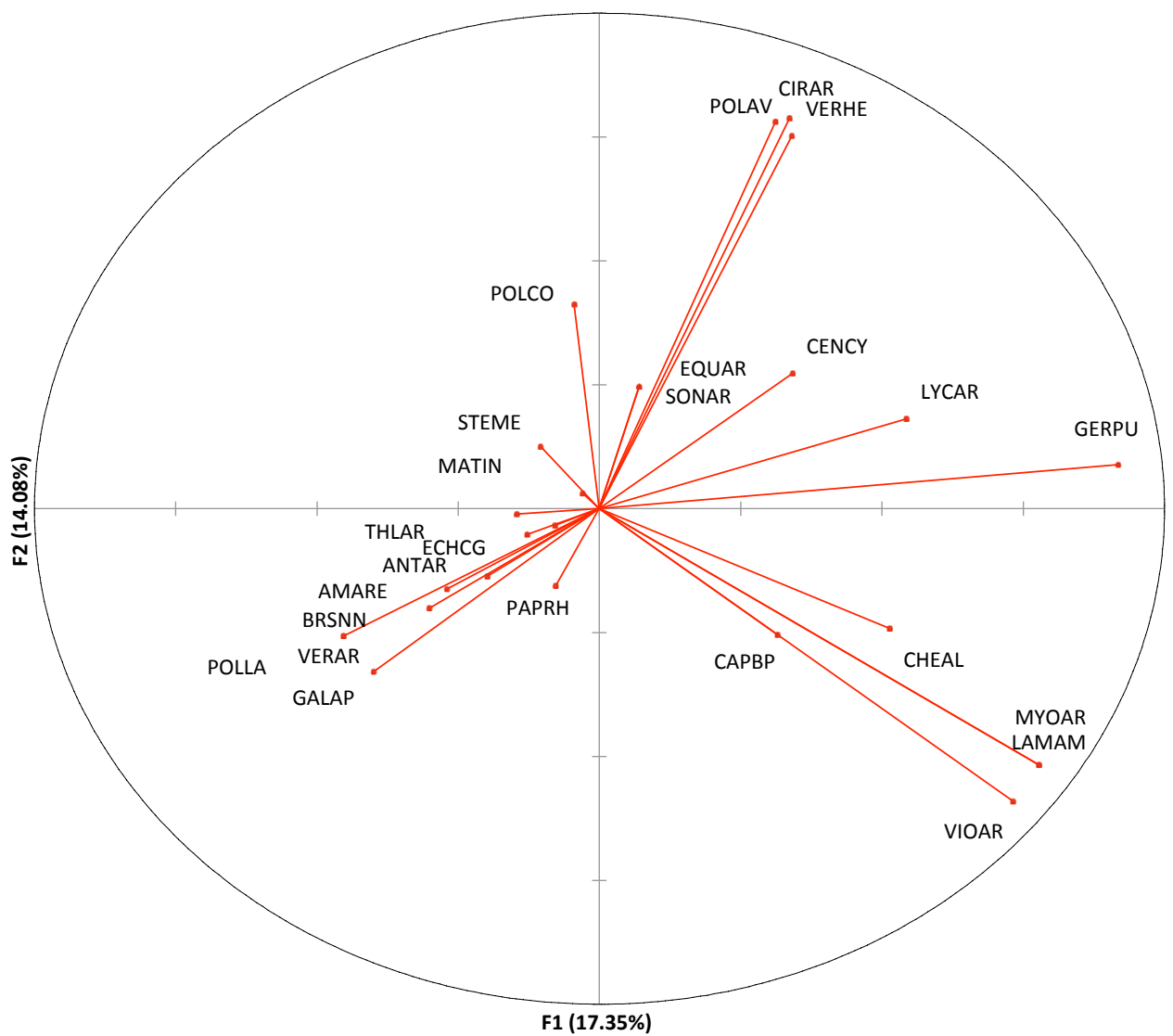

Fig. 3 Relationship between weed species in spring barley in Winna Góra based on the means for 1993-2012 as described by principal component analysis (PCA). Weed codes: AMARE-Amaranthus retroflexus, LYCAR - Anchusa arvensis, ANTAR - Anthemis arvensis, BRSNN - Brassica napus volunteer, CAPBP - Capsella bursa pastoris, CENCY - Centaurea cyanus, CHEAL - Chenopodium album, CIRAR - Cirsium arvense, ECHCG - Echinochloa crus-galli, EQUAR - Equisetum arvense, POLCO - Fallopia convolvulus, GALAP - Galium aparine, GERPU - Geranium pusillum, LAMAM - Lamium amplexicaule, MATIN - Matricaria maritima spp. inodora, MYOAR - Myosotis arvensis, PAPRH - Papaver rhoeas, POLAV - Polygonum aviculare, POLLA - P. lapathifolium, SONAR - Sonchus arvensis, STEME - Stellaria media, THLAR - Thlaspi arvense, VERHE - Veronica arvensis, VERAR - V. hederifolia, VIOAR - Viola arvensis.

During the spring vegetation periods in the dry years, the yield loss caused by weed infestation was highest (Fig. 5). On average, the grain yield was lower by $21.6 \%$ than that obtained from the herbicide-treated area. In the very dry years, the yield loss was higher by $6.0 \%$ than that in the moderately dry and wet years when the yield loss reached $15.5 \%$ and $15.9 \%$, respectively, as compared with the weed controlled area.

\section{Discussion}

The total precipitation and mean air temperature highly varied during the spring vegetation periods of the study years. In the analysis of meteorological conditions prevailing in Poland in the years 1971-2000, Skowera and Puła [35] demonstrated considerable variability of pluvio-thermal conditions during the spring vegetation periods, where the number of extremely wet and extremely dry months was similar.

The highest phytosociological stability (V) and the most abundant occurrence were noted for Chenopodium album and Viola arvensis. These species are characterized by low soil moisture requirements, hence they grow well during wet and dry years $[36,37]$. They represent segetal plants of the highest frequency in all regions of Poland [38]. Mediumfrequent species (III) were represented by Galium aparine and Matricaria maritima ssp. inodora. Infrequent species (II) included Capsella bursa-pastoris, Fallopia convolvulus, Polygonum lapathifolium, and Stellaria media. The other species occurred sporadically.

In the study, the occurrence of segetal weeds in the spring barley crop was analyzed in relation to different temperature and humidity conditions prevailing over the last twenty 


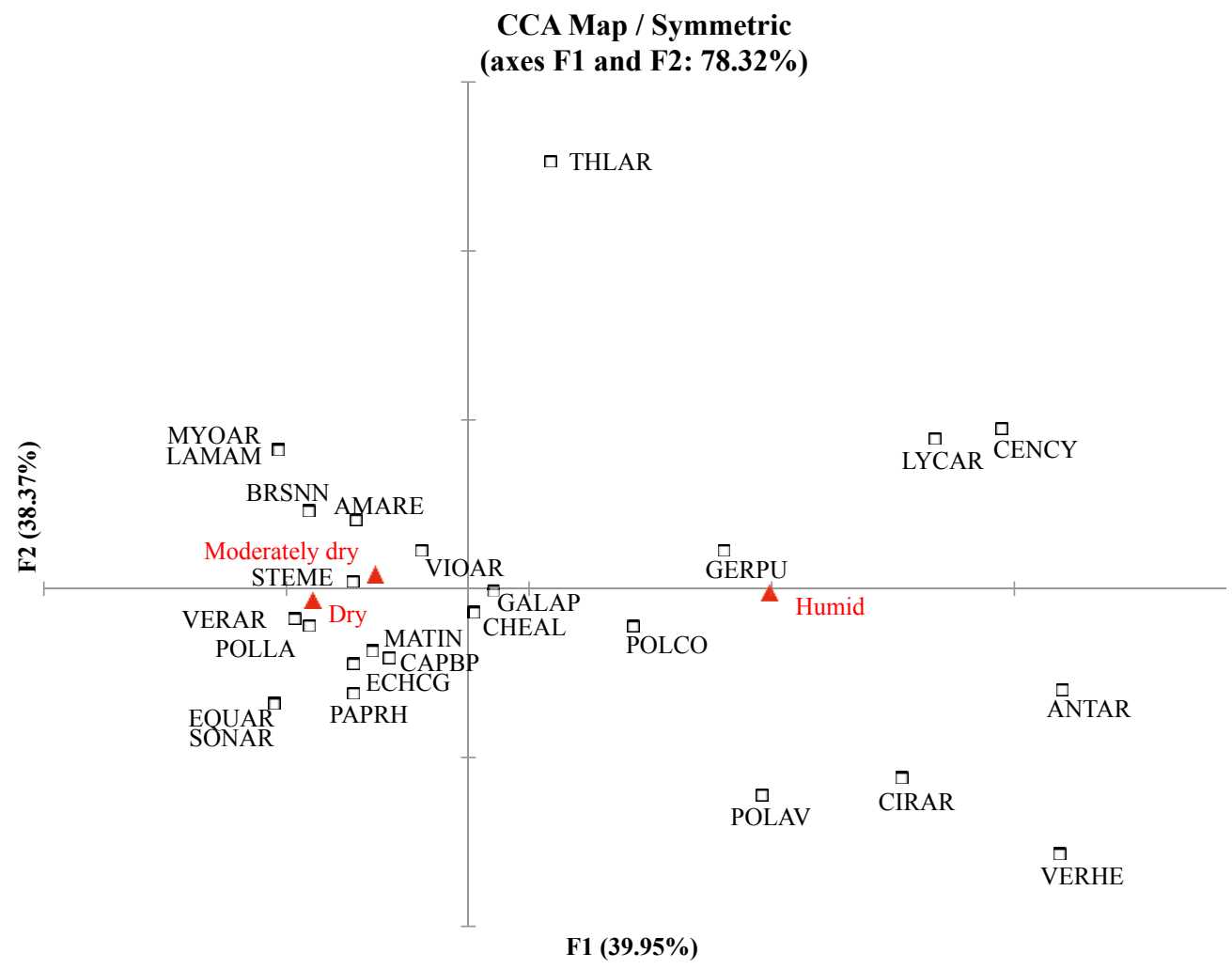

$\square$ Weed species $\Delta$ Vegetation season

Fig. 4 The distribution of 19 weed species in spring barley depending on pluvio-thermal conditions (AprilJune) in Winna Góra in the years 1993-2012. Canonical correspondence analysis (CCA) ordination diagram with weed species (white square) and vegetation season (red triangle). Weed codes see explanation for Fig. 3.

years. During the last decade of the 20th century and the first decade of the 21st century, a clear systematic increase in air temperature and highly varied precipitation rates were reported. Especially over the last 20 years, distinct warming and large fluctuations in precipitation trends were noted during the periods of spring cereal vegetation, which is undoubtedly reflected in the dynamics of the species composition and species biodiversity of weed communities. Thermal-humidity conditions exert an impact on weed infestation rates in crops. In the investigations carried out

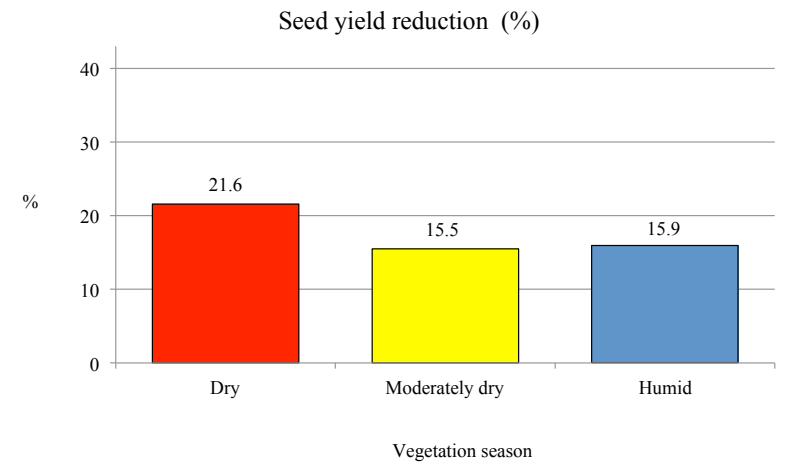

Fig. 5 Effect of weed infestation on the reduction in spring barley yield depending on pluvio-thermal conditions (April-June) in Winna Góra (the means for 1993-2012). by Wanic et al. [29], the abundance of weeds in spring barley was significantly positively correlated with the precipitation rates during the spring months. In our study, the calculated ecological indices exhibited variability depending on the pluvio-thermal conditions. In the years characterized by more favorable meteorological conditions (as assessed by the Sielianinov hydrothermal coefficient), during the spring vegetation period the highest species diversity and the lowest species dominance were noted. Evaluation of biodiversity is prompted by both research and economic needs [17]. The lower values of the Shannon-Wiener index and the higher values of the Simpson index reported under less favorable pluvio-thermal conditions should be explained by the lower ability of crop plants to compete with weeds. Dominant species $\left(p_{i}^{2}\right)$ in the weed community were shown on the basis of the highest values. In the wet and moderately dry years, two species, i.e., Chenopodium album and Viola arvensis, dominated among the infesting species, while in the very dry years they were accompanied by Matricaria maritima spp. inodora and Galium aparine (Tab. 2).

Multivariate statistical analysis based on the method of weighted averaging of indicator species was proposed by the ecologists, i.e., Gause (1930) and Ellenberg (1948) [39-41]. In this paper, statistical tools (PCA, CCA) were used to make graphic maps of the relationship between the weed community in spring barley and weather conditions. 
Tab. 2 Index of weed species dominance calculated for particular weeds noted in spring barley depending on pluvio-thermal conditions (April-June) in Winna Góra (the means from 1993-2012).

\begin{tabular}{|c|c|c|c|c|}
\hline \multirow[b]{2}{*}{ No. } & \multirow[b]{2}{*}{ Species } & \multicolumn{3}{|c|}{ Index of weed species dominance $\left(p_{i}^{2}\right)$} \\
\hline & & $k \leq 0.7$ & $0.7<k<1.3$ & $k>1.3$ \\
\hline 1 & Chenopodium album $\mathrm{L}$. & 0.27 & 0.34 & 0.30 \\
\hline 2 & Viola arvensis Murray & 0.08 & 0.06 & 0.05 \\
\hline 3 & Galium aparine L. & 0.02 & + & 0.01 \\
\hline 4 & Matricaria maritima L. subsp. inodora (L.) Dostál & 0.08 & 0.01 & + \\
\hline 5 & Thlaspi arvense $\mathrm{L}$. & + & + & 0.01 \\
\hline 6 & Stellaria media (L.) Vill. & + & + & - \\
\hline 7 & Fallopia convolvulus (L.) Á. Löve & - & + & + \\
\hline 8 & Polygonum lapathifolium L. & 0.01 & + & - \\
\hline 9 & Capsella bursa-pastoris (L.) Medik. & + & + & + \\
\hline 10 & Anthemis arvensis $\mathrm{L}$. & - & - & + \\
\hline 11 & Veronica hederifolia L. s.s. & - & - & + \\
\hline 12 & Brassica napus L. subsp. napus & + & + & - \\
\hline 13 & Centaurea cyanus $\mathrm{L}$. & + & - & + \\
\hline 14 & Echinochloa crus-galli (L.) P. Beauv. & - & + & - \\
\hline 15 & Lamium amplexicaule $\mathrm{L}$. & + & - & - \\
\hline 16 & Veronica arvensis $\mathrm{L}$. & + & + & - \\
\hline 17 & Cirsium arvense (L.) Scop. & - & + & + \\
\hline 18 & Myosotis arvensis (L.) Hill & + & - & - \\
\hline 19 & Sonchus arvensis $\mathrm{L}$. & + & - & - \\
\hline 20 & Anchusa arvensis (L.) M. Bieb. & + & - & + \\
\hline 21 & Polygonum aviculare $\mathrm{L}$. & + & + & + \\
\hline 22 & Amaranthus retroflexus $\mathrm{L}$. & - & + & - \\
\hline 23 & Geranium pusillum Burm. f. ex L. & + & - & + \\
\hline 24 & Papaver rhoeas L. & - & + & - \\
\hline 25 & Equisetum arvense $\mathrm{L}$. & + & - & - \\
\hline
\end{tabular}

“+” - sporadically occurring species, value $<0.01$; “”” - the species did not occur.

CCA describes the relationships between species and the environment by assuming a response model that is common to all species and the existence of a single set of underlying environmental gradients to which all the species respond [34]. The results showed that the occurrence of Chenopodium album and Viola arvensis was not dependent on weather conditions. Many data in the literature indicate that these weed species most infest spring cereals [38,42-48].

The presence of large numbers of weeds in cultivated fields is not desirable [49], but negligible quantities do not cause a significant yield reduction [50]. Weed control should be applied with consideration of not only yield loss but also ecological aspects and conservation of biodiversity of the environment so that the adverse impact of anthropopressure on the environment can be limited [36]. In unfavorable conditions for spring barley growth (precipitation deficiency in spring), the competitiveness of barley plants towards weeds is reduced. Therefore, one should expect a greater threat to crops of spring cereals (including barley) through competitive interaction of dominant weed species, particularly during a prolonged dry spring period.

\section{Conclusions}

In the 20-year period analyzed, Chenopodium album and Viola arvensis exhibited the highest phytosociological stability and the highest abundance in spring barley regardless of weather conditions.

In the years with favorable meteorological conditions, the species diversity of weeds in the spring vegetation period was higher than in the years with precipitation deficiency.

In the dry years, the species dominance index in the spring vegetation period was higher than in the wet years.

Chenopodium album and Viola arvensis, were the dominant weed species infesting the spring barley crop; they were accompanied by Matricaria maritima spp. inodora and Galium aparine in the dry years.

The yield loss caused by weed infestation in the very dry years was higher by $6 \%$ compared with the moderately dry and wet years.

In the 20-year period analyzed, dry spring vegetation periods dominated and they were characterized by substantial precipitation deficiency between late April and mid-June. 


\section{Acknowledgments}

Research supported by the Ministry of Science and Higher Education of Poland as part of the statutory activities of the Department of Weed Science and Plant Protection Techniques, Plant Protection Institute - National Research Institute in Poznań.

\section{Authors' contributions}

The following declarations about authors' contributions to the research have been made: idea and design of the study: RKi, RKr; acquisition and processing of results: $\mathrm{RKr}, \mathrm{RKi}, \mathrm{KA}$; analysis and interpretation of data: $\mathrm{RKr}, \mathrm{RKi}$; drafting of manuscript: $\mathrm{RKr}$.

\section{Competing interests}

No competing interests have been declared.

\section{References}

1. Central Statistical Office of Poland. Statistical yearbook of agriculture, Warsaw: Central Statistical Office of Poland; 2004-2014.

2. Budzyński W, Szemplński W. Jęczmień. In: Jasińska Z, Kotecki A, editors. Szczegółowa uprawa roślin. Wrocław: Wydawnictwo Akademii Rolniczej; 2003. p. 195-233.

3. Buczyński G, Marks M. Spring barley weed infestation and yield in crop rotation and monoculture. Zesz Probl Postępów Nauk Rol. 2003;490:41-47.

4. Monaco TJ, Weller SC, Ashton FM. Weed science principles and practices. New York, NY: John Wiley \& Sons, Inc.; 2002.

5. Paradowski A. Integrowana metoda ograniczania zachwaszczenia. In: Korbas M, Mrówczyński M, editors. Integrowana produkcja jęczmienia ozimego i jarego. Poznań: Instytut Ochrony Roślin - Państwowy Instytut Badawczy; 2010. p. 46-74.

6. Adamczewski K, Dobrzański A. Przyszłość herbologii w zmieniającym się rolnictwie. Prog Plant Prot Post Ochr Roślin. 2012;52(4):867-878.

7. Albrecht $\mathrm{H}$. Changes in the arable weed flora of Germany during the last five decades. In: Proceedings of the 9th EWRS (European Weed Research Society) Symposium "Challenges for Weed Science in a Changing Europe”; 1995 Jul 10-12; Budapest, Hungary. Budapest: EWRS; 1995. p. 41-48.

8. Andersson NT, Milberg P. Weed flora and the relative importance of site, crop, crop rotation and nitrogen. Weed Sci. 1998;46:30-38.

9. Barberi P, Silvestri N, Bonami E. Weed communities of winter wheat as influenced by input level and rotation. Weed Res. 1997;37:301-313. http://dx.doi.org/10.1046/j.1365-3180.1997.d01-53.x

10. Chancellor RJ. Changes in the weed flora of arable field cultivated for 20 years. J Appl Ecol. 1985;22:491-501. http://dx.doi.org/10.2307/2403180

11. Falińska K. Ekologia roślin. Warszawa: Wydawnictwo Naukowe PWN; 2012.

12. Korniak T, Hołdyński C. Charakterystyka flory segetalnej północnowschodniej części Polski. In: Conference proceedings: "Przyczyny i źródła zachwaszczenia pól uprawnych”; 1994 Jun 28-29; OlsztynBęsia, Poland. Olsztyn: Akademia Rolniczo-Techniczna; 1995. p. 7-12.

13. Krawczyk R, Matysiak K, Kierzek R, Kaczmarek S, HoroszkiewiczJanka J. Kształtowanie zachwaszczenia w uprawie pszenicy ozimej w okresie konwersji gruntów ornych na metodę ekologiczną. J Res Appl Agric Engng. 2010;55(3):195-199.

14. Weber R, Hryńczuk B, Hryńczuk-Runowska B. Effect of long-term fallow tillage method on weed abundance in the first three years of fallow being brought into cultivation. EJPAU. 2004;7(2):23-37.

15. Rola H, Rola J. Pozytywne i negatywne aspekty stosowania herbicydów w uprawach rolniczych w Polsce w latach 1950-2000. Prog Plant Prot Post Ochr Roślin. 2001;41:47-57.

16. Stupnicka-Rodzynkiewicz E, Stępnik K, Lepiarczyk A. Wpływ zmianowania, sposobu uprawy roli i herbicydów na bioróżnorodność zbiorowisk chwastów. Acta Sci Pol Agric. 2004;3(2):235-245.

17. Sienkiewicz J. Koncepcje bioróżnorodności - ich wymiary i miary w świetle literatury. Ochrona Środowiska i Zasobów Naturalnych. 2010;45:7-29.
18. Gołębiowska H, Snopczyński T. Wzrost zagrożenia zachwaszczeniem wtórnym na plantacji kukurydzy na tle zróżnicowanego przebiegu pogody. Prog Plant Prot Post Ochr Roślin. 2008;48(2):602-611.

19. Kierzek R, Miklaszewska K, Krawczyk R, Matysiak K. Wpływ terminu nalistnego stosowania w kukurydzy mieszanin herbicydów na ich efektywność chwastobójczą. Prog Plant Prot Post Ochr Roślin. 2011;51(4):1836-1841.

20. Adamczewski K, Praczyk T, Stachecki S. Wpływ opadów atmosferycznych i temperatury powietrza na występowanie niektórych gatunków chwastów oraz ich konkurencyjność w stosunku do roślin uprawnych. In: Conference proceedings: "Przyczyny i źródła zachwaszczenia pól uprawnych”; 1994 Jun 28-29; Olsztyn-Bęsia, Poland. Olsztyn: Akademia Rolniczo-Techniczna; 1995. p. 109-116.

21. Dobrzański A. Wpływ niektórych czynników środowiska, ze szczególnym uwzględnieniem wilgotności, na zachwaszczenie upraw warzyw. In: Conference proceedings: "Przyczyny i źródła zachwaszczenia pól uprawnych”; 1994 Jun 28-29; Olsztyn-Bęsia, Poland. Olsztyn: Akademia Rolniczo-Techniczna; 1995. p. 117-124.

22. Heller K, Adamczewski K. Wpływ wybranych warunków pogodowych na stan i stopień zachwaszczenia łanu lnu włóknistego. Frag Agron. 2010;27(3):63-69.

23. Rola J, Radziszewski J, Badowski M, Rola H. Wpływ powodzi w 1997 roku na zachwaszczenie pól uprawnych. Pamięt Puł. 1999;115:17-24.

24. Ziernicka-Wojtaszek A, Zawora T. Zróżnicowanie pluwiotermiczne Polski w świetle współczesnych zmian klimatu. Acta Agrophys. 2008;12(1):289-297.

25. Żmudzka E. Współczesne zmiany klimatu Polski. Acta Agrophys. 2009;13(2):555-568

26. Krawczyk R. Kierunki zmian zachwaszczenia - szanse i zagrożenia. Prog Plant Prot Post Ochr Roślin. 2005;45(1):233-241.

27. Mirek Z, Piękoś-Mirkowa H, Zając A, Zając M, editors. Flowering plants and pteridophytes of Poland - a checklist. Kraków: W. Szafer Institute of Botany, Polish Academy of Sciences; 2002. (Biodiversity of Poland; vol 1).

28. Matuszkiewicz W. Przewodnik do oznaczania zbiorowisk roślinnych Polski. Warszawa: Wydawnictwo Naukowe PWN; 2012

29. Wanic M, Jastrzębska M, Kostrzewska MK, Nowicki J. Analiza zbiorowisk chwastów za pomocą wybranych wskaźników biologicznych. Acta Agrobot. 2005;58(1):227-242. http://dx.doi.org/10.5586/ aa.2005.026

30. Krebs CJ. Ekologia. Eksperymentalna analiza rozmieszczenia i liczebności. Warszawa: Wydawnictwo Naukowe PWN; 2011.

31. Weiner J. Życie i ewolucja biosfery. Warszawa: Wydawnictwo Naukowe PWN; 2012.

32. Topham PB, Lawson HM. Measurement of weed species diversity in crop/weed competition studies. Weed Res. 1982;22:285-293. http:// dx.doi.org/10.1111/j.1365-3180.1982.tb00174.x

33. Trzpiot G, editor. XLSTAT w analizie danych. Katowice: Uniwersytet Ekonomiczny w Katowicach; 2014.

34. ter Braak CJF. Canonical correspondence analysis: a new eigenvector technique for multivariate direct gradients. Ecology. 1986;67:11671179. http://dx.doi.org/10.2307/1938672

35. Skowera B, Puła J. Skrajne warunki pluwiotermiczne w okresie wiosennym na obszarze polski w latach 1971-2000. Acta Agrophys. 2004;3(1):171-177.

36. Dobrzański A, Adamczewski K. Wpływ walki z chwastami na bioróżnorodność agrofitocenoz. Prog Plant Prot Post Ochr Roślin. 2009;49(3):982-995.

37. Tymrakiewicz W. Atlas chwastów. Warszawa: Powszechne Wydawnictwo Rolnicze i Leśne; 1959.

38. Latowski K. Problem pospolitych chwastów segetalnych Polski. Prog Plant Prot Post Ochr Roślin. 2002;42(1):392-399.

39. Gause GE. Studies on the ecology of the Orthoptera. Ecology. 1930;11:307-325. http://dx.doi.org/10.2307/1930266

40. Ellenberg H. Unkrautgesellschaften als Mass fur den Sauregrad, 
die Verdichtung und andere Eigenschaften des Ackerbodens. Ber Landtech. 1948;4:130-146.

41. ter Braak CJF, Verdonschot PFM. Canonical correspondence analysis and related multivariate methods in aquatic ecology. Aquat Sci. 1995;57(3):255-289. http://dx.doi.org/10.1007/BF00877430

42. Kapeluszny J. Zachwaszczenie łanu zbóż jarych w warunkach zróżnicowanej gęstości siewu i oszczędnego stosowania herbicydów. Prog Plant Prot Post Ochr Roślin. 2002;42(2):483-485.

43. Krawczyk R. Produkcja biomasy przez Chenopodium album L. $\mathrm{w}$ jęczmieniu jarym odchwaszczanym chemicznie zredukowanymi i zalecanymi dawkami herbicydów. Ann Univ Mariae CurieSkłodowska E Agric. 2007;62(2):40-47.

44. Walczak F, Grendowicz L, Jakubowska M, Skorupska A, Strugała N, Tratwal A, et al. Szkodliwość ważniejszych agrofagów roślin uprawianych oraz stan zachwaszczenia w Polsce w 2001 roku. Prog Plant Prot Post Ochr Roślin. 2002;42:262-282.

45. Rola H. Ekologiczne i produkcyjne aspekty ochrony roślin przed chwastami. Pamiet Puł. 130;2002:636-645.

46. Wesołowski M, Dąbek M, Stępień A, Kwiatkowski C. Wpływ gęstości wysiewu oraz poziomu agrotechniki pszenicy jarej na strukturę zachwaszczenia jej łanu. Acta Agrophys. 2003;1(4):779-785.

47. Kwiatkowski C, Wesołowski M, Stępień A. Bioróżnorodność chwastów w trzech odmianach jęczmienia jarego uprawianych w siedmioletniej monokulturze i zmianowaniu. Acta Sci Pol Agric. 3(2);2004:109-117

48. Feledyn-Szewczyk B, Duer I. Efektywność metod regulacji zachwaszczenia $\mathrm{w}$ jęczmieniu jarym uprawianym $\mathrm{w}$ różnych systemach produkcji. Prog Plant Prot Post Ochr Roślin. 2006;46(1):45-52.

49. Rola H, Rola J, Domaradzki K. Przyrodnicza optymalizacja zbiorowisk chwastów w agrocenozach. Prog Plant Prot Post Ochr Roślin. 2009;49(3):1102-1111.

50. Domaradzki K. Efektywność regulacji zachwaszczenia zbóż w aspekcie ograniczania dawek herbicydów oraz wybranych czynników agroekologicznych. Puławy: Instytut Uprawy Nawożenia i Gleboznawstwa; 2006. (Monografie i Rozprawy Naukowe; vol 17).

\section{Zmiany stanu zachwaszczenia jęczmienia jarego w zależności od zmiennych warunków pluwiotermicznych}

\section{Streszczenie}

Celem pracy była analiza zbiorowiska chwastów segetalnych w uprawie jęczmienia jarego na tle zmian warunków pluwiotermicznych w okresie dwudziestoletnim (1993-2012) na terenie Polowej Stacji Doświadczalnej Instytutu Ochrony Roślin - Państwowego Instytutu Badawczego w Winnej Górze. W analizowanych latach dla trzech miesięcy wiosennej wegetacji (kwiecień, maj i czerwiec) dokonano oceny warunków pluwiotermicznych z zastosowaniem współczynnika hydrotermicznego Sielianinowa, co pozwoliło na wyznaczenie trzech okresów (bardzo suchy, umiarkowanie suchy, wilgotny). Ocenę składu florystycznego w uprawie jęczmienia jarego przeprowadzono wg skali Braun-Blanqueta. Zgromadzone dane posłużyły do wyliczenia wskaźników: różnorodności gatunkowej Shannona-Wienera i dominacji Simpsona. W badanym dwudziestoleciu Chenopodium album i Viola arvensis charakteryzowały się najwyższym stopniem stałości fitosocjologicznej oraz występowały najliczniej w uprawie jęczmienia jarego. W tym okresie na obszarze prowadzonych obserwacji w okresie wegetacji wiosennej występowała przewaga lat suchych, ze znacznym niedoborem opadów w okresie od końca kwietnia do połowy czerwca. W latach o korzystnym przebiegu warunków meteorologicznych notowano większą różnorodność gatunkową chwastów niż w latach z niedoborem opadów. W latach bardzo suchych wartość indeksu dominacji gatunkowej Simpsona była wyższa niż w latach wilgotnych. W zachwaszczeniu jęczmienia jarego dominowały Chenopodium album i Viola arvensis, a w latach bardzo suchych również Matricaria maritima spp. inodora. Utrata plonu jęczmienia jarego, w skutek zachwaszczenia, w latach bardzo suchych była większa o $6 \%$ w porównaniu do lat umiarkowanie suchych i lat wilgotnych. 